\title{
Analysis of spatial patterns of oak decline in cork oak woodlands in Mediterranean conditions
}

\author{
Augusta Costa*, Helena PEREIRA, Manuel MadeIRA \\ Instituto Superior de Agronomia, Centro de Estudos Florestais, Universidade Técnica de Lisboa, Tapada da Ajuda 1349 - 017 Lisboa, Portugal
}

(Received 21 January 2009; accepted 8 July 2009)

Keywords:

Quercus suber L./

oak decline /

remote sensing /

logistic regression /

oak mortality

\begin{abstract}
- Cork oak mortality is a recurrent problem in southwestern Portugal. Despite the perception of increasingly visible damage in oak woodlands on drought-prone sites, the role of the various environmental factors in their decline is not clear.

- To describe the spatial patterns of cork oak (Quercus suber L.) mortality, a cork oak mortality index $(M I)$ was determined for each landscape feature (agroforestry system, soil type, slope and aspect) using a GIS approach. To achieve this goal, a logistic regression model was formulated analyzing interactions between landscape attributes and allowing a prediction of cork oak mortality.

- Maximum values of $M I$ were found in (i) shrublands and open woodlands with shrub encroachment (MI 6 and 3, respectively), where competition for soil water between tree and understory increases; and (ii) on lower slopes in the rounded hilltops and smooth hillsides or shallow soils where access to groundwater resources during summer drought is difficult.

- The model highlighted the importance of the agroforestry systems on cork oak mortality and may be used to identify sensitive areas where mitigation actions should be employed in a scenario of increasing drought severity in these Mediterranean ecosystems.
\end{abstract}

Résumé - Analyse des modèles spatiaux de dépérissement du chêne dans les forêts de chêne liège dans les conditions méditerranéennes.

- La mortalité du chêne liège est un problème récurrent dans le sud-ouest du Portugal. Malgré la perception de dommages de plus en plus visibles dans les forêts de chênes sur les sites propices à la sécheresse, le rôle des différents facteurs environnementaux dans leur déclin n'est pas clair.

- Pour décrire les schémas spatiaux de la mortalité du chêne liège (Quercus suber L.), un indice de mortalité des chênes lièges $(M I)$ a été déterminé pour chaque élément du paysage (système agroforestier, type de sol, pente et exposition) en utilisant une approche SIG. Pour atteindre cet objectif, un modèle de régression logistique a été formulé pour analyser les interactions entre les attributs du paysage et permettre une prédiction de la mortalité du chêne liège.

- Les valeurs maximum des $M I$ ont été trouvées dans (i) les zones arbustives et les forêts claires avec empiètement d'arbustes (MI 6 et 3 , respectivement), où la concurrence pour l'eau du sol entre les arbres et le sous-bois s'accroît; et (ii) dans le bas des pentes du sommet des collines arrondies et les pentes douces de coteaux ou sur les sols peu profonds où l'accès aux ressources souterraines en eau est difficile en période de sécheresse estivale.

- Le modèle a mis en évidence l'importance des systèmes agroforestiers dans la mortalité des chêneslièges et peut être utilisé pour identifier les zones sensibles où des actions de mitigation devraient être employées dans un scénario d'augmentation de la sévérité des sécheresses dans ces écosystèmes méditerranéens.

\section{INTRODUCTION}

The cork oak (Quercus suber L.) is a common oak species in the Iberian Peninsula and the most important one in the evergreen oak open forests of the western Mediterranean region. In Portugal it covers 737 thousand ha, corresponding to

\footnotetext{
* Corresponding author: augusta.costa@efn.com.pt
}

$23 \%$ of the national forest area (DGRF, 2007), and is the dominant species of the "montado" agroforestry system, which combines cork production with extensive agriculture or pasture and livestock (Pereira and Tomé, 2004; Pinto-Correira and Mascarenhas, 1999).

Cork oak decline has been reported in south-western Portugal since the 1890s (Cabral et al., 1992). It is a major concern 
regarding the sustainability of these forests and for ensuring the raw-material supply for the cork industry. Cork oak decline has been described as a widespread and complex phenomenon, triggered by decrease of tree vigor and physiological stress (e.g. drought) and subsequent attack by pathogens, similarly to what occurs in Europe (Brasier, 1996; Ferreira, 2000; Oszako, 2000; Thomas et al., 2002) and North America (Fortin et al., 2008; Kabrick et al., 2008; Oak et al., 1996). Associations between some stand-site attributes and cork oak decline were suggested by Cabral et al. (1993). The progressive crown dieback was associated with xeric site conditions of shallow soils or hydromorphic soil conditions (David et al., 1992; Diniz, 1994; Sousa et al., 2000), defoliation, insect attacks, pathogenic fungi (Brasier, 1996: Moniz et al., 1996; Wargo, 1996) and inappropriate silvicultural management (Cadima et al., 1995) that could seriously threatened the long-term maintenance of trees.

The occurrence of cork oak decline was assumed to be caused by a combination of primary or predisposing factors, and secondary or opportunistic factors (Cabral et al., 1993; Thomas et al., 2002). There is a fairly broad consensus about the role of water availability in the primary causes, given the similarity of symptoms of cork oak decline and of chronic water deficits (Kurz-Besson et al., 2006). Although cork oaks are well-adapted to summer drought and to limited water availability (Costa et al., 2002; Oliveira et al., 1992), their distribution is related to drought severity, hydromorphic site conditions and the soil-site-water availability relation (Costa et al., 2008; David et al., 2007; Kabrick et al., 2008). Disease is therefore unlikely to be the only primary cause of oak decline, and consequentially attention should be focused on the environmental influences on cork oak decline.

A severe or prolonged drought can act as a predisposal factor for the decline of physiologically mature oaks (Brasier, 1996; Bréda, 2000; Oak et al., 1996; Wargo, 1996), while at local level landscape physical attributes such as edaphic conditions, slope and land use disturbances (e.g. shrub encroachment) can induce highly variable moisture conditions with different impacts on the trees (Costa et al., 2008; Cubera et al., 2004; Montero et al., 2004). The description of the spatial patterns of cork oak decline at landscape level could therefore provide a better understanding on its possible causes as well as on the relationship between the soil-site-water availability and tree decline. However, there is no information on the landscape distribution of cork oak decline that could be used for this type of analysis.

A case study was carried out in S. Bartolomeu da Serra, representative of a large area of cork oak woodlands in southwestern Portugal, hypothesizing that cork oak mortality in Mediterranean conditions is related to landscape features, such as agroforestry systems, slope, aspect and soil type. The study also aimed at determining whether oak decline severity is proportionally greater on poorer sites and/or on more extensive land use systems. The spatial patterns of cork oak mortality were characterized at landscape level using remote sensed data, and the probability to find an area with cork oak mortality was predicted based on a logistic regression model using landscape attributes. The results were used to identify the most sensitive areas where mitigation actions would be most effectively employed to prevent cork oak mortality in a scenario of increasing drought severity in these Mediterranean ecosystems.

\section{MATERIALS AND METHODS}

\subsection{Study area}

The study area is located in south-western Portugal within the Submediterranean ecologic region at the county of S. Bartolomeu da Serra, between $38^{\circ} 04^{\prime} \mathrm{N}-8^{\circ} 40^{\prime} \mathrm{W}$ and $37^{\prime} 56^{\prime} \mathrm{N}-8^{\circ} 34^{\prime} \mathrm{W}$, with a total area of 6224 hectares (Fig. 1). It is representative of the large cork oak woodland area in Portugal, and managed as a traditional silvo-pastoral system mainly for cork production and for livestock, with grazing areas intercropped with pasture areas of grasslands and legumes, and with fallow areas (Pinto-Correia and Vos, 2004). The annual cork production is $177 \mathrm{~kg} \mathrm{ha}^{-1}$ (DGF, 2001).

The climate is of the Mediterranean type with oceanic influence, with a mean relative humidity between $77 \%$ and $84 \%$, and the highest temperatures during summer when rainfall is lowest. Mean annual rainfall is $676 \mathrm{~mm}$, mainly concentrated in late autumn, winter and early spring (INAG data for the period 1950-2006). Long-term mean annual temperature is $15.9{ }^{\circ} \mathrm{C}$, with a mean temperature for the coldest month of $9.9^{\circ} \mathrm{C}$ (January) and $21.8^{\circ} \mathrm{C}$ for the hottest month (July) (INAG data for the period 1954-2006).

Two geomorphologic areas can be found: one flat or gentle undulating area located in the central eastern part of the county, and one larger steep undulating area with rounded to flat hilltops and with smooth hillsides (Fig. 1). In the first area, the elevation ranges from 120 to $180 \mathrm{~m}$ a.s.l. and is dominated by slopes up to $15 \%$; in the second, the elevation ranges between 85 and $263 \mathrm{~m}$ a.s.1. and is dominated by slopes between $5-35 \%$ with higher slopes $(>35 \%)$ in small areas near the main water lines.

Geological formations are mostly schists (grauwakes, siltstones and carbonaceous schists) with vertical stratification and, to a small extent, sedimentary formations of the Plio-Plistocenic (sandstones with variable clay content and sands) (Inverno et al., 1993). Sandstones and sands overly the schist formations in the rounded flattened hilltops.

The soils are mostly related to the nature of the geological substrate, according to the Portuguese Soil Map (SROA, 1962). On schist formations, the dominant soils are Haplic Leptosols (LPx) (sensu WRB, 2006) with a depth to compact rock lower than $25 \mathrm{~cm}$; in flat and gentle undulating areas, Epileptic Luvisols (LVx), with compacted rock between 25 and $50 \mathrm{~cm}$ depth also occur. Both Leptosols and Luvisols developed on schists show silty clay to silty clay loam texture. On sandstones (mostly clay sandstones), soils are mostly Haplic Leptosols (LPst) and the texture is sandy clay loam to sandy clay, while on sands soils are mostly Haplic Arenosols (AR) and texture is sandy to loam sandy. Fluvisols (FV) occur only in small areas. LPx, LVx and LPst have similar bulk densities, which are lower than those for AR (Tab. I).

Soils in the study area showed similar $\mathrm{pH}$ values. Contents of organic $\mathrm{C}$ and exchangeable $\mathrm{Ca}$ and $\mathrm{Mg}$ were similar in soils developed on schists and on sandstones, but much higher than those observed in Arenosols. All the soils had very low content of extractable P (Tab. I).

The study area is within a biogeographical unit characterized by the dominant species of the Myrto-Quercetum suberis association 


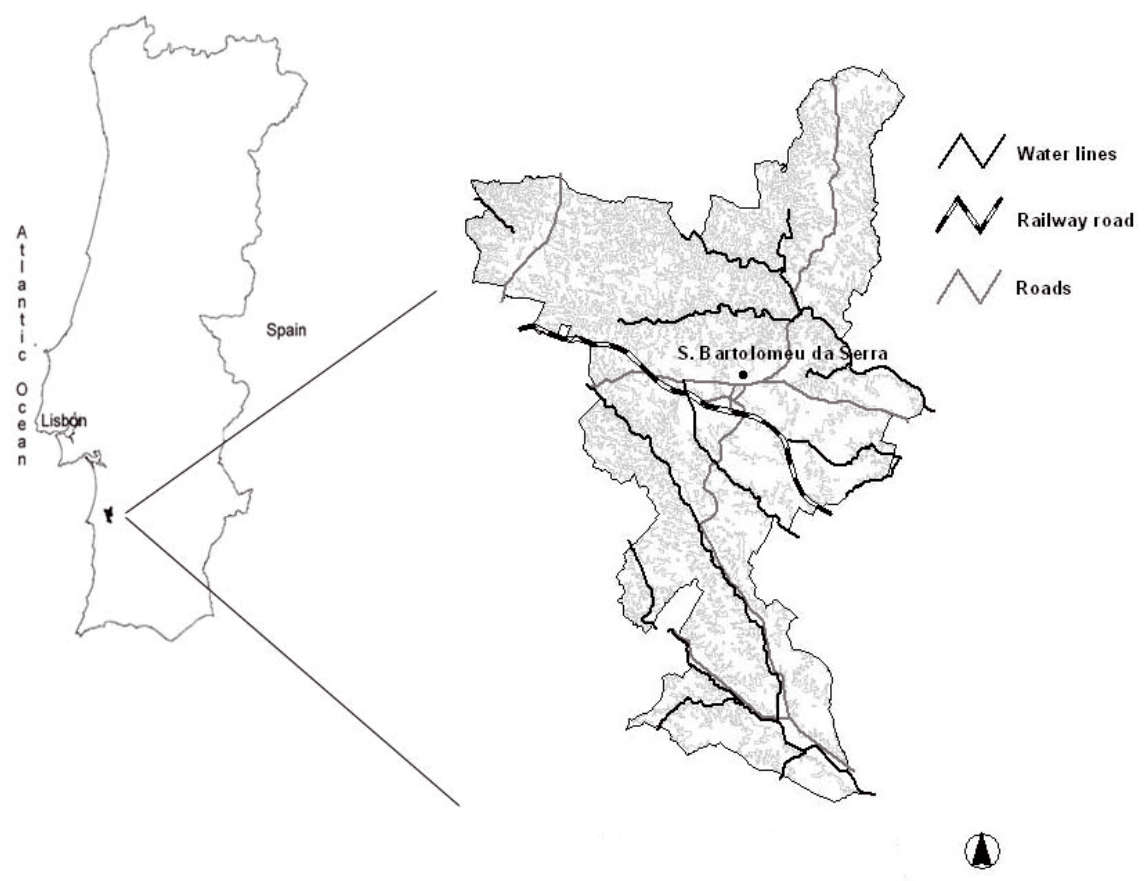

Figure 1. Location of the study area in S. Bartolomeu da Serra (6224 ha).

Table I. Range of bulk density (BD) and selected chemical characteristics in the $0-15 \mathrm{~cm}$ top soil layer of soils of S. Bartolomeu da Serra. (LPx - Haplic Leptosols on schists; LVx - Epileptic Luvisols; LPst - Haplic Leptosols on sandstones; AR - Haplic Arenosols).

\begin{tabular}{lccccccc}
\hline Soil units & $\begin{array}{c}\mathrm{BD}^{\mathrm{a}} \\
\left(\mathrm{g} \mathrm{cm}^{-3}\right)\end{array}$ & $\mathrm{pH}\left(\mathrm{H}_{2} \mathrm{O}\right)$ & $\begin{array}{c}\mathrm{Org} \mathrm{C}^{\mathrm{b}} \\
\left(\mathrm{g} \mathrm{kg}^{-1}\right)\end{array}$ & $\begin{array}{c}\text { Exch Ca } \\
\left(\mathrm{cmol}_{\mathrm{c}} \mathrm{kg}^{-1}\right)\end{array}$ & $\begin{array}{c}\mathrm{Exch} \mathrm{Mg}^{\mathrm{c}} \\
\left(\mathrm{cmol}_{\mathrm{c}} \mathrm{kg}^{-1}\right)\end{array}$ & $\begin{array}{c}\mathrm{Ext} \mathrm{P}^{\mathrm{d}} \\
\left(\mathrm{mg} \mathrm{kg}^{-1}\right)\end{array}$ & $\begin{array}{c}\mathrm{Ext} \mathrm{K}^{\mathrm{d}} \\
\left(\mathrm{mg} \mathrm{kg}^{-1}\right)\end{array}$ \\
\hline LPx; LVx & $1.09-1.20$ & $5.6-6.2$ & $19.4-25.2$ & $2.09-3.70$ & $1.52-2.60$ & $1.88-2.69$ & $106-196$ \\
LPst & $1.15-1.25$ & $5.5-6.0$ & $19.6-22.6$ & $1.82-2.59$ & $1.88-2.18$ & $0.15-0.87$ & $38-80$ \\
AR & $1.32-1.38$ & $5.1-6.2$ & $6.1-14.2$ & $0.28-0.83$ & $0.06-0.21$ & $1.07-4.40$ & $9-26$ \\
\hline
\end{tabular}

${ }^{a}$ Determined in undisturbed samples. ${ }^{b}$ By the wet oxidation method. ${ }^{c}$ Extracted by ammonium acetate at $\mathrm{pH} 7 .{ }^{\mathrm{d}}$ Extracted by the Egnér-Riehm method.

and underlying shrubs of the association Genisto hirsutae-Cistetum ladaniferi (Costa et al., 1998). Since 1975 only four small fires occurred (in 1991, 2002 and 2003) with a total of 85 ha burnt area, mainly in shrublands (Pereira and Santos, 2003).

\subsection{Data preparation}

A cartographic analysis of the study area was made based on the digital aerial photographs taken in the summer of 2005 with a $0.5-\mathrm{m}$ spatial resolution and ortho-rectified and projected onto the National Coordinate System (Gauss Projection, datum 73 Lisbon).

The methodology comprised: (i) the cartographic analysis of landscape composition; (ii) the delimitation of the cork oak and of the cork oak mortality areas; (iii) the characterization of landscape patterns and of cork oak woodland attributes in mortality areas; and (iv) the prediction of cork oak mortality areas at the landscape level based on logistic regression model with GIS (geographic information system) variables.
The following landscape composition classes were considered in the photo-interpretation: woodlands, shrublands, agriculture lands, social areas and water areas. The minimum mapping unit area (patch area) was 0.5 ha for all classes except for water areas, which could be smaller and for linear formations (e.g. houses or roads) where the minimum mapping unit had $20 \mathrm{~m}$ width. The landscape composition was quantified by the sum of areas covered by each class.

The cork oak area comprised the areas where cork oak was the dominant species, and the cork oak mortality area was defined as the area with occurrence of oak decline symptoms such as crown thinning, discoloration of leaves, crown reduction and tree dehydration, in single trees, or in small areas within the stands. These areas were delimitated using the remote sensed data and were confirmed by direct field observation, following the methodology of the National Forest Service, for which a $90 \%$ accuracy for photo-interpretation could be assumed.

The cork oak area was distributed by the three vegetation classes of landscape composition (or cork oak agroforestry systems): woodlands, agriculture lands and shrublands. 
Woodlands were defined by a tree density over 20 trees per hectare and were classified by: forest composition (identification of tree dominant/dominated species); forest structure (identification of a regular/irregular stand and mature/juvenile stand); by canopy cover in three classes of tree crown area percentage of total area (clear: $<25 \%$; open: $25-50 \%$; dense: $>50 \%$ ) by density, number of trees per ha, divided into three classes (low: 20 to 40 trees per ha; medium: 40 to 80 trees per ha; high: more than 80 trees per ha); and by understory in three classes of dominant vegetation underlying the trees (agriculture: dominated by cultivated annual/biannual herbaceous plant communities in pastures alternating with fallow, traditionally used for extensive livestock raising; shrubs: dominated by shrub species in areas with low intensity land use but submitted to shrub management and; shrub encroachment: with an increase of woody plant cover, dominated by encroaching shrub species). The agriculture lands had a cork oak density over 5 trees per hectare with underlying natural grasslands or legumes for fodder, occasionally cultivated for cereal crops. Shrublands corresponded to shrub encroachment areas with a cork oak density over 5 trees per hectare used traditionally for hunting.

The cork oak mortality was classified into three classes: with no mortality (less than or equal to 1 dead tree per hectare), with normal mortality (between 1 to 5 dead trees per hectare) and with mortality (more than 5 dead trees per hectare).

A cork oak mortality index $(M I)$ was calculated for each class either of cork oak landscape vegetation, or of stand features (e.g., woodlands, slope or understory classes) or their combinations, based on the equation (1) where $\mathrm{a}_{k i}$ is the area of the patch $i$ classified "with mortality" of the class $k, A_{k}$ is the total patch area of the class $k$ and $n$ is the number of patches "with mortality" of the class $k$ :

$$
M I=\operatorname{Int}\left(\frac{\sum_{i=1}^{n} \mathrm{a}_{k i}}{A_{k}} \times 10\right) .
$$

A spatial database was constructed including soil and topographic information. The geo-referenced digital cover of the Portuguese Soil Map at 1:25 000 scale (SROA, 1962) was used and the Reference Soil Groups (WRB, 2006) adapted from the Portuguese Soil Classification (Cardoso, 1965) were applied in the study. The digital aspect and slope maps were constructed with a 10-m spatial resolution based on the digital terrain model (DTM) derived from a 1: 25000 topographic map from the Portuguese Army Geographic Institute. Five aspect classes were considered: none (no dominant aspect), north $\left(0^{\circ}-45^{\circ}\right.$ and $315^{\circ}-360^{\circ}$, east $\left(45^{\circ}-135^{\circ}\right)$, south $\left(135^{\circ}-225^{\circ}\right)$ and west $\left(225^{\circ}-315^{\circ}\right)$ and four slope classes: flat $(<5 \%)$, gentle $(5-15 \%)$, undulated $(15-35 \%)$ and steep (>35\%).

\subsection{Cork oak mortality probability modeling}

The correlation between cork oak mortality and spatial patterns was assessed in a randomly selected sample of cork oak patches classified in two groups "with mortality" and "with no or normal mortality", covering the variation of landscape attributes. The sampling was based on a balanced experimental design with a number of patches proportional to the covered surface in each landscape stratum. A univariate logistic regression analysis (SPSS, 2008) was made on the GIS data in order to characterize the relative importance of the categorical variables soil type, aspect, slope, understory and canopy cover in the occurrence of cork oak mortality in the three vegetation classes.

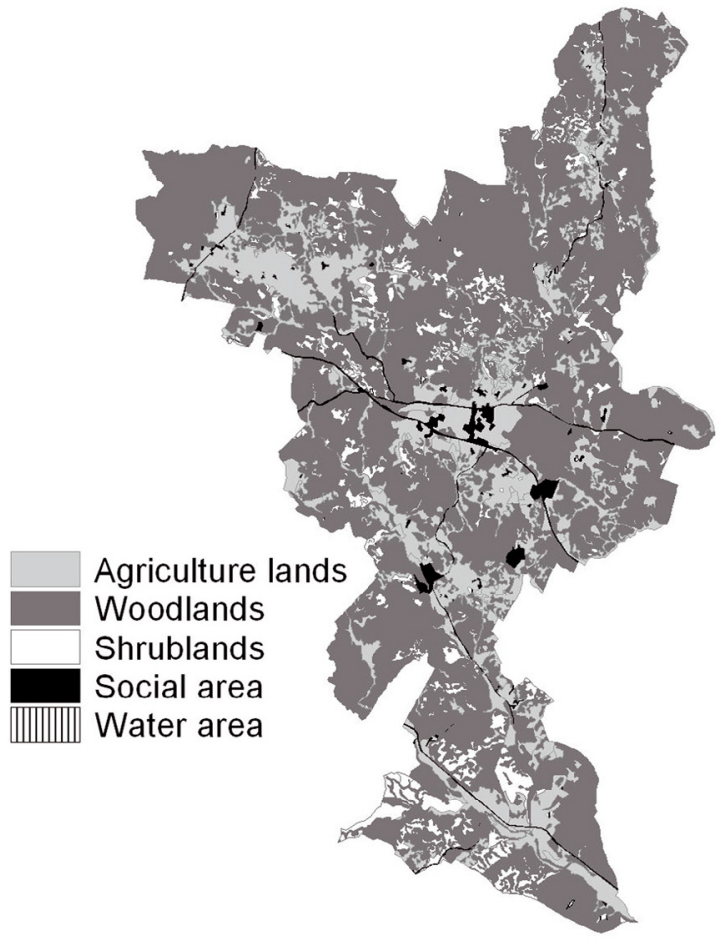

Figure 2. S. Bartolomeu da Serra land cover in 2005 based on five main land use classes: Woodlands, Agriculture areas, Shrublands, Social and Water areas.

A multivariate analysis using forward stepwise logistic regression (SPSS, 2008) modeled the above referred to GIS data and selected a set of independent variables which could explain, in a logical and statistically significant way, the probability of the cork oak mortality in a given site. The predictors were selected taking into account the log-likelihood ratio tests (to determine whether the addition of a variable improved significantly the model).

The cork oak mortality probability model was applied to the total cork oak area and a probability map for cork oak mortality was generated and compared with the observed cork oak mortality map. The match between the predicted cork oak mortality (considering a cut value of 0.5 ) and the observed mortality occurrence was analyzed within each landscape stratum.

\section{RESULTS}

\subsection{Landscape composition and structure}

In S. Bartolomeu da Serra the woodlands were the dominant land use followed by agriculture areas and shrublands (Fig. 2). Woodlands corresponded to $69 \%$ of the total study area, while agriculture lands represented $22 \%$ and shrublands $8 \%$. Social and water areas were $2 \%$ of total area (Tab. II).

Shrublands were the most fragmented vegetation class with a mean patch area of 1.7 ha, followed by woodlands (2.3 ha), while agriculture lands showed the lowest spatial fragmentation with a mean of 4.0 ha (Tab. II). 
Table II. Landscape composition and structure of S. Bartolomeu da Serra in 2005 derived from interpretation of aerial photographs.

\begin{tabular}{clll}
\hline Landscape classes & $\begin{array}{l}\text { Area } \\
\text { (ha) }\end{array}$ & $\begin{array}{l}\text { Mean patch } \\
\text { area (ha) }\end{array}$ & $\begin{array}{l}\text { No. of } \\
\text { patches }\end{array}$ \\
\hline Total area & & & \\
Woodlands & 4269 & 2.3 & 1853 \\
Agriculture & 1345 & 4.0 & 336 \\
Shrublands & 479 & 1.7 & 283 \\
Cork oak area & & & \\
Woodlands & 4236 & 2.3 & 1814 \\
Agriculture & 369 & 1.9 & 220 \\
Shrublands & 417 & 2.2 & 165 \\
Cork oak mortality area & & & \\
Woodlands & 556 & 1.9 & 291 \\
Agriculture & 67 & 3.7 & 18 \\
Shrublands & 211 & 2.5 & 85 \\
\hline
\end{tabular}

Table III. Characterization of the cork oak woodlands (total area 4236 ha) of S. Bartolomeu da Serra in 2005 in relation to canopy cover and type of understory derived from interpretation of aerial photographs.

\begin{tabular}{lcccc}
\hline Canopy cover & $\begin{array}{c}\text { Understory } \\
\text { herbaceous }\end{array}$ & Shrub & $\begin{array}{c}\text { Shrub } \\
\text { encroachment }\end{array}$ & Total \\
\hline$<25 \%$ & 535 & 174 & 311 & 1020 \\
$25-50 \%$ & 725 & 97 & 158 & 979 \\
$>50$ & 1355 & 621 & 261 & 2237 \\
Total & 2615 & 891 & 730 & 4236 \\
\hline
\end{tabular}

\subsection{Cork oak area}

Cork oak was the dominant tree species, occupying 5023 ha, that corresponded to $81 \%$ of the study area (Tab. II). Cork oak woodlands were the dominant landscape stratum with $84 \%$ of the total cork oak area and cork oak shrublands and agriculture lands represented only $8 \%$ and $7 \%$, respectively. Similar mean patch areas were found in these three cork oak agroforestry systems although slightly lower in agriculture lands (Tab. II).

The cork oak woodlands were mostly uneven-aged mature stands that resulted from the management of naturally regenerated stands with a large percentage of trees under cork exploitation. More than half of the cork oak woodlands area (2237 ha) were dense woodlands with a canopy cover $>50 \%$, and the dominant understory was herbaceous, corresponding to $62 \%$ of the cork oak woodlands area. Shrub encroachment was found in $17 \%$ of the cork oak woodlands and was more noticed in the clear canopy cover class (Tab. III).

In the cork oak area, soils were mainly Haplic Leptosols (LPx) and Epileptic Luvisols (LVx), representing respectively $78 \%$ and $19 \%$ of the area. On schist formations, Luvisols were mainly found in the flat or gentle undulating areas: $50 \%$ and
Table IV. The cork oak area (ha) and cork oak mortality index $(M I)$ in brackets discriminated by strata: Woodlands, Agriculture and Shrublands, by aspect and slope classes.

\begin{tabular}{clllll}
\hline & Aspect & & & & \\
& None & North & East & South & West \\
\hline Woodlands & $1627[1]$ & $735[1]$ & $573[1]$ & $663[2]$ & $638[1]$ \\
$<5 \%$ & $1562[1]$ & $41[1]$ & $36[2]$ & $42[2]$ & $38[2]$ \\
$>35 \%$ & $28[1]$ & $238[1]$ & $169[1]$ & $135[2]$ & $150[1]$ \\
Agriculture & $162[2]$ & $29[2]$ & $40[2]$ & $77[2]$ & $62[1]$ \\
$<5 \%$ & $158[2]$ & $3[0]$ & $5[3]$ & $8[1]$ & $7[2]$ \\
$>35 \%$ & $1[3]$ & $2[1]$ & $2[1]$ & $5[0]$ & $4[1]$ \\
Shrublands & $166[5]$ & $39[5]$ & $45[5]$ & $91[6]$ & $75[5]$ \\
$<5 \%$ & $160[5]$ & $4[7]$ & $3[4]$ & $4[9]$ & $3[4]$ \\
$>35 \%$ & $2[2]$ & $5[2]$ & $8[4]$ & $16[5]$ & $14[3]$ \\
\hline
\end{tabular}

$30 \%$ of Luvisols in the cork oak area were on the slope classes $<5 \%$ and $5-15 \%$, respectively. In contrast, Leptosols (LPx) occupied both flat and steep undulating areas: $40 \%$ and $20 \%$ of Leptosols in the cork oak area were on the slope classes $<5 \%$ and $>35 \%$, respectively. Haplic Leptosols developed on sandstones (LPst), Arenosols (AR) and Fluvisols (FV) occupied only $3 \%$ of the total cork oak area mainly in the flat or gentle undulating areas.

The cork oak area occurred mainly in slopes up to 5\% and with no dominant aspect (1 880 ha, $37 \%$ of total cork oak area) (Tab. IV). In low and medium slopes $(<35 \%)$ the cork oak area was distributed rather evenly by aspect, while in steep undulating areas (>35\%) it was mainly oriented towards north ( $31 \%$ of the total steep undulating area).

\subsection{Cork oak mortality}

The cork oak mortality area was scattered over the whole cork oak area (Fig. 3) totaling 834 ha. The mortality occurred in small areas in woodlands (corresponding to $13 \%$ of cork oak woodlands with a mean patch area of 1.9 ha) and in agriculture lands (corresponding to $18 \%$ of the cork oak agriculture area). Mortality was predominant in shrublands where it occurred in $51 \%$ of the area. The mean patch area of cork oak mortality was larger in agriculture and shrublands, respectively 3.7 ha and 2.5 ha (Tab. II).

The overall mortality index $(M I)$ of the cork oak area was 2 , but with a distinct occurrence in the three agroforestry systems: in shrublands $M I$ was maximal and equal to 6 while in woodlands and in agriculture lands the $M I$ were 1 and 2, respectively (Tab. V).

The cork oak mortality index in woodlands was also significantly different in the three types of understory (Tab. V). The $M I$ increased threefold in areas with shrub encroachment in relation to those with herbaceous or with shrub communities. The highest value $(M I=5)$ was found in areas with shrub encroachment and clear canopy cover $(<25 \%)$ and the lowest value in woodlands with a dense canopy cover $(>50 \%)$ and herbaceous understory $(M I=0)$.

In relation to soil type, cork oak mortality was mainly located in Leptosols on schists (LPx, almost $87 \%$ of cork oak 


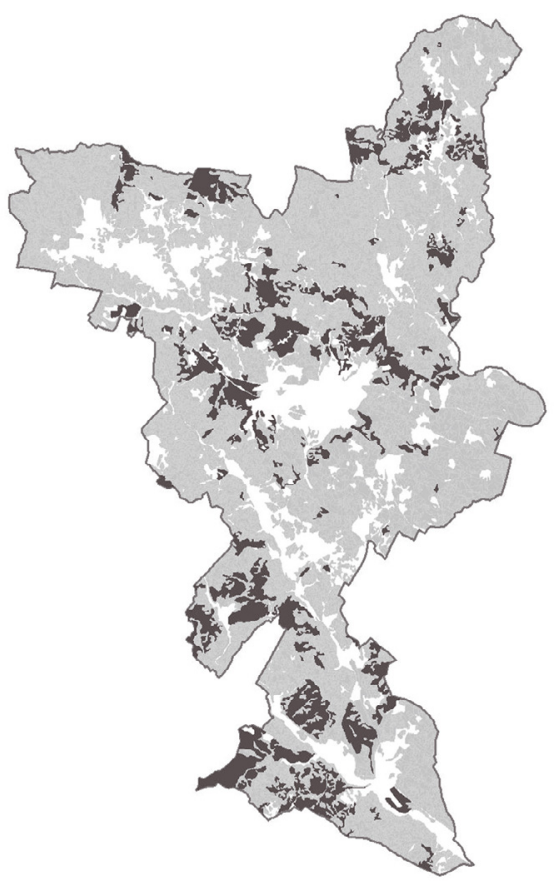

Figure 3. Cork oak area (light grey) and cork oak mortality area (dark grey) at S. Bartolomeu da Serra) in the year of 2005.

Table V. Cork oak mortality index $(M I)$ in S. Bartolomeu da Serra in 2005 discriminated by agroforestry system (understory, in woodlands) and soil type (LPx - Haplic Leptosols on schists; LVx Epileptic Luvisols; LPst - Haplic Leptosols on sandstones; AR Haplic Arenosols).

\begin{tabular}{lcccc}
\hline & \multicolumn{4}{c}{ Reference Soil Group } \\
& LPx & LVx & AR & LPst \\
\hline Woodlands & 1 & 1 & 1 & 2 \\
Herbaceous & 1 & 0 & 1 & - \\
Shrub & 1 & 2 & - & 5 \\
Shrub encroachement & 4 & 2 & - & 7 \\
Agriculture & 2 & 2 & - & 9 \\
Shrublands & 5 & 7 & - & 10 \\
\hline
\end{tabular}

mortality area) where it represented a $M I$ of 2 , but the highest $M I$ values were found in Leptosols developed on sandstones (LPst, $M I=6$ ) with the maximum value of 10 in shrublands (Tab. V).

Shrublands showed the highest $M I$ with maximum values in south dominant aspect especially in areas with slopes up to $15 \%$ ( $M I$ of 9 and 7, respectively for slope classes $<5 \%$ and 5-15\%). The lowest $M I$ was found in woodlands, with minimum values in north aspect areas $(M I=1)$ and slightly higher in south aspect areas $(M I=2)$. Overall mortality increased in the south aspect and occurred mainly in areas with slopes up to $35 \%$ (Tab. IV).
Table VI. Logistic regression "odds ratio" for independent variables for with cork oak mortality/without or normal cork oak mortality area.

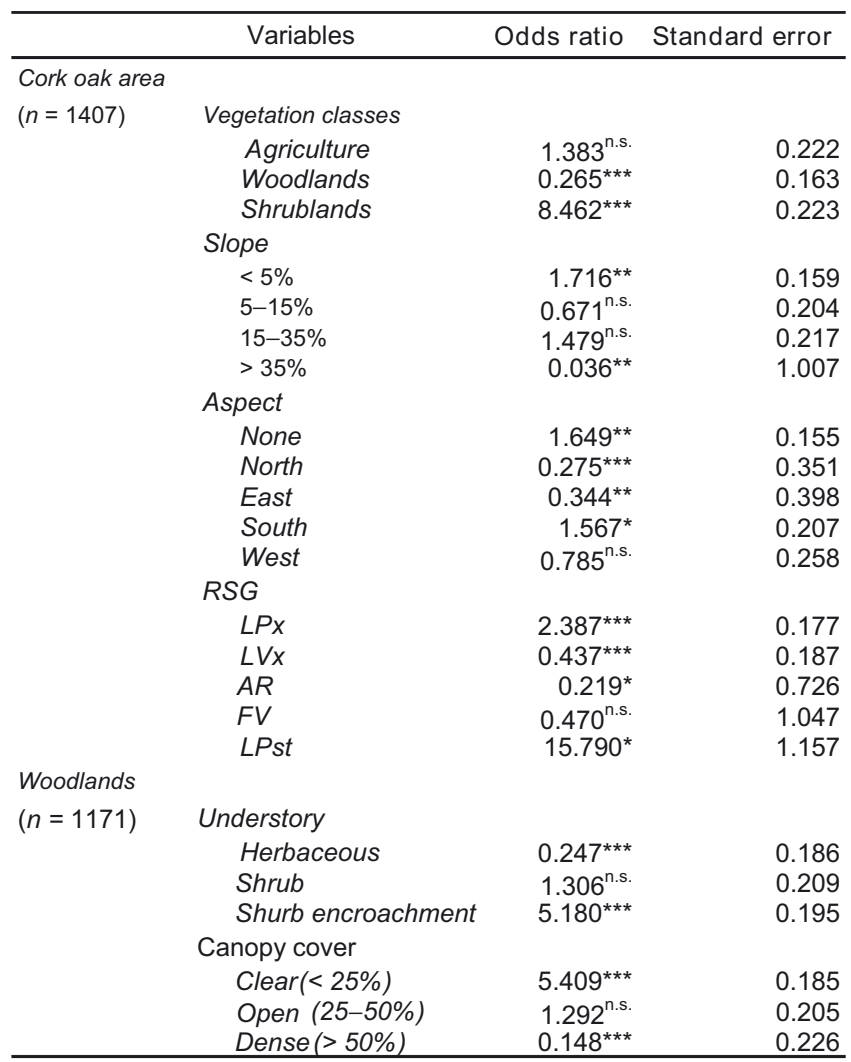

Wald-test statistic: $P$ values: $P<0.001-* * * ; P<0.01-* * ; P<0.05$

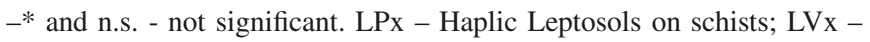
Epileptic Luvisols; LPst - Haplic Leptosols on sandstones; AR - Haplic Arenosols; FV - Fluvisols.

\subsection{Predicting cork oak mortality}

The logistic regressions of cork oak mortality with landscape variables showed that the highest odds ratio values were found for sedimentary formations (Haplic Leptosols), where cork oak mortality was predicted to occur almost 16 times more frequently, while in Leptosols on schist formations it was almost 2.5 times higher. In shrublands the cork oak mortality prediction was 8 times higher than in other land uses (Tab. VI). On schists, Leptosols (LPx) were predicted to have double mortality of that of Luvisols (LVx).

Lower mortality was predicted with significant probability for steep slopes (> 35\%) and for north and east aspects, and in contrast higher mortality was predicted for flat slopes $(<5 \%)$ and for south and no dominant aspects (Tab. VI).

The probability of occurrence of cork oak mortality in cork oak woodlands was slightly inferior to that in the other agroforestry systems. When considering only woodlands, the cork oak mortality was 5 times more likely to occur in clear woodlands (canopy cover $<25 \%$ ) or with shrub encroachment than in other woodlands. Relatively less cork oak mortality 
Table VII. Regression coefficient of mortality probability model, their standard deviation (S.E.) and statistical significance for categorical variables: Agroforestry system, Aspect, Soil Group and Slope).

\begin{tabular}{lcccc}
\hline Variable & $B$ (coefficient) & S.E. & Wald statistic & Significance \\
\hline Agroforestry system & & & 65.892 & 0.000 \\
Agriculture lands & -1.207 & 0.314 & 14.729 & 0.000 \\
Woodlands & -1.860 & 0.235 & 62.879 & 0.000 \\
Aspect & & & 18.003 & 0.001 \\
North & 0.255 & 0.613 & 0.174 & 0.677 \\
East & 0.228 & 0.637 & 0.128 & 0.720 \\
South & 1.649 & 0.567 & 8.465 & 0.004 \\
West & 1.021 & 0.562 & 3.294 & 0.070 \\
Slope & & & 14.258 & 0.003 \\
$<5 \%$ & 4.130 & 1.139 & 13.145 & 0.000 \\
$5-15 \%$ & 2.954 & 1.040 & 8.060 & 0.005 \\
15-35\% & 3.183 & 1.036 & 9.440 & 0.002 \\
Soil & & & 31.131 & 0.000 \\
LPx & -2.313 & 1.248 & 3.433 & 0.064 \\
LVx & -3.331 & 1.250 & 7.103 & 0.008 \\
AR & -3.979 & 1.436 & 7.684 & 0.006 \\
FV & -3.820 & 1.656 & 5.324 & 0.021 \\
Constant & -1.482 & 0.743 & 34.221 & 0.000 \\
\hline
\end{tabular}

occurred in dense woodlands (canopy cover $>50 \%$ ) and with herbaceous understory (Tab. VI).

A multivariate logistic regression model with all selected GIS variables using forward stepwise method was built with a $\chi^{2}$ significant at $p<0.001(11.603 * * *)$. All variables included in the logistic model were significant according to the Wald test $(\alpha=0.05)$. The predictors included in the cork oak mortality logistic model could be roughly divided into two groups: categorical variable describing the agroforestry management system with three levels ( $1=$ agriculture lands; $2=$ woodlands and 3 = shrublands (the default reference category) and categorical variables describing site conditions, namely soil, with five levels: $1=\mathrm{LPx} ; 2=\mathrm{LVx} ; 3=\mathrm{AR} ; 4=\mathrm{FV}$ and $5=$ LPst (the default reference category); slope with four levels: $1=<5 \% ; 2=5-15 \% ; 3=15-35 \%$ and $4=>35 \%$ (the default reference category) and; aspect with five levels: $1=$ north; 2 = east; $3=$ south; $4=$ west and $5=$ no dominant aspect (the default reference category).

According to the model (Tab. VII) the agroforestry management system is one strong predictor, and all dummy variables were statistically significantly different from the dummy variable 3 ( $p$-value $<0.001$ ). A change in agroforestry systems, from woodlands to shrublands will increase the mortality by 5 times while a change from agriculture lands to shrublands will also increase the mortality but by almost 3 times.

Soil variables showed that only dummy variables $2=\mathrm{LVx}$ and 3 = AR were statistically significantly different from the dummy variable $5=$ LPst $(p$-value $<0.05)$ and a change of soil from LVx to LPst will increase the mortality by 22 times. In relation to aspect, only the dummy variables $3=$ south was statistically significantly different from the dummy $5=$ no dominant aspect $(p$-value $<0.05)$, and a change of aspect from south to no dominant aspect will increase the mortality by 5 times.
For slope, all dummy variables were statistically significantly different from the dummy variable 4 ( $p$-value $<0.05)$ and mortality is more likely to occur in all slope classes than in steep slopes, e.g. in the flat areas the mortality is 62 times higher than in steep slopes.

In spite of the model's high overall accuracy (85\%), the prediction accuracy for the areas without or with normal mortality was $97.2 \%$ but only $21.6 \%$ for the areas with mortality, when considering a cut-off value of 0.50 in the classification. The predicted probability of cork oak mortality was always lower in woodlands and higher in shrublands, where the predicted probability of cork oak mortality was higher than 0.5 in most classes of landscape features (Fig. 4).

Considering all GIS variables, the maximum value of predicted probability (0.95) was estimated for shrublands in Haplic Leptosols on sandstones with dominant south aspect and in gentle undulating slopes (5-15\%), followed by the predicted probability of 0.74 for shrublands in LPx with south aspect and in undulating slopes (15-35\%).

The probability of cork oak mortality occurrence was mapped for all the cork oak area based on the logistic regression model by adding to each cork oak area patch its predicted probability of cork oak mortality (Fig. 5). The predicted cork oak mortality area was located mainly in the steep undulating area. Great similarities were found between the predicted cork oak mortality area and the observed cork oak mortality area (Fig. 3).

The overall accuracy of prediction in cork oak woodlands was $81 \%$ but only $22 \%$ of the area "with mortality" was correctly classified while prediction of "without mortality or with normal mortality" was correct in $91 \%$ of the area. In shrublands the overall accuracy was $53 \%$ with a correct classification in $90 \%$ of the area "with mortality" and only $15 \%$ of the area "without mortality or normal mortality".

\section{DISCUSSION}

The present study showed that cork oak mortality in Mediterranean conditions is related to landscape features, such as agroforestry system, slope, aspect and soil type. The distribution of decline consistently suggested that site conditions, which directly influence the tree water availability, are stressful landscape factors that contribute to the onset of cork oak mortality. This is in agreement with findings which have been also reported for deciduous oaks in the southeastern United States (Kabrick et al., 2008; Oak et al., 1996) and in central Europe (Brasier, 1996; Oszako, 2000; Thomas et al., 2002).

The management system was a significant mortality predictor that should be included in oak mortality models to increase its accuracy. In fact, in the study area, the land use extensification was related to high mortality probabilities, and the incidence of cork oak mortality greatly differed between agroforestry systems with the lowest mortality in woodlands and the highest mortality in shrublands.

In woodlands most of the cork oak mortality was found in areas with a clear canopy cover and with shrub encroachment and the lowest in areas with a dense canopy cover and 
a)

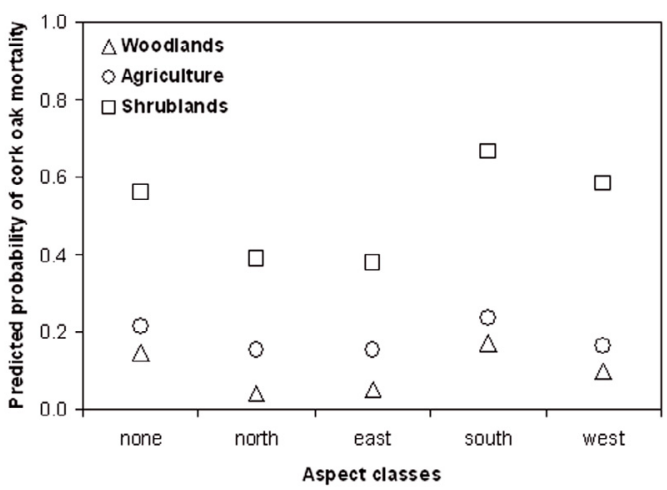

b)

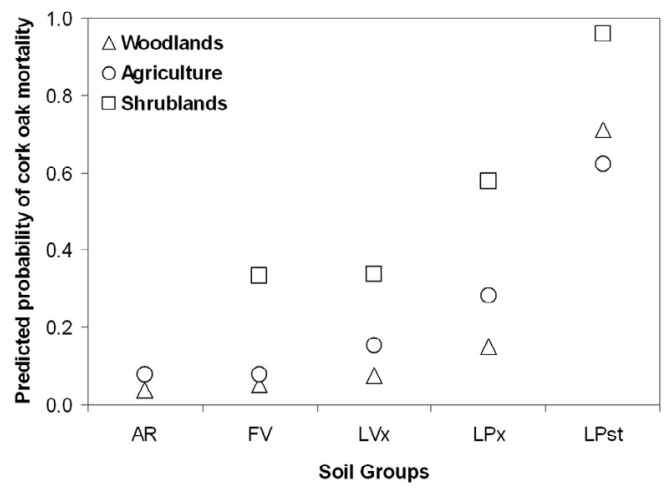

c)

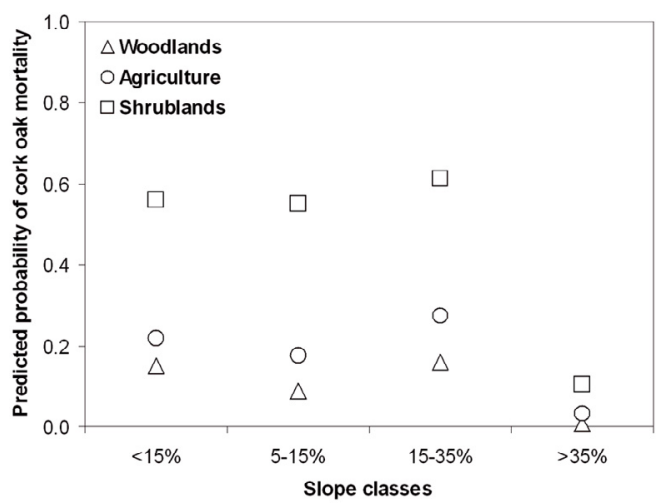

Figure 4. Predicted probability cork oak mortality (mean value) discriminated by agroforestry system: woodlands, shrublands and agriculture lands in relation to: (a) aspect; (b) soil groups (LPx - Haplic Leptosols on schists; LVx - Epileptic Luvisols; LPst - Haplic Leptosols on sandstones; AR - Haplic Arenosols; FV - Fluvisols) and (c) slope.

with herbaceous understory. This is in agreement with observations made in a region with similar geologic formations and soil type, where the shrub encroachment dominated by Cistus ladanifer $\mathrm{L}$. was considered to be a decisive factor for water availability and tree decline (Cabral et al., 1992; Cadima et al., 1995). Those patterns may also be associated with the findings for encroached holm oak "dehesas" (in central-western

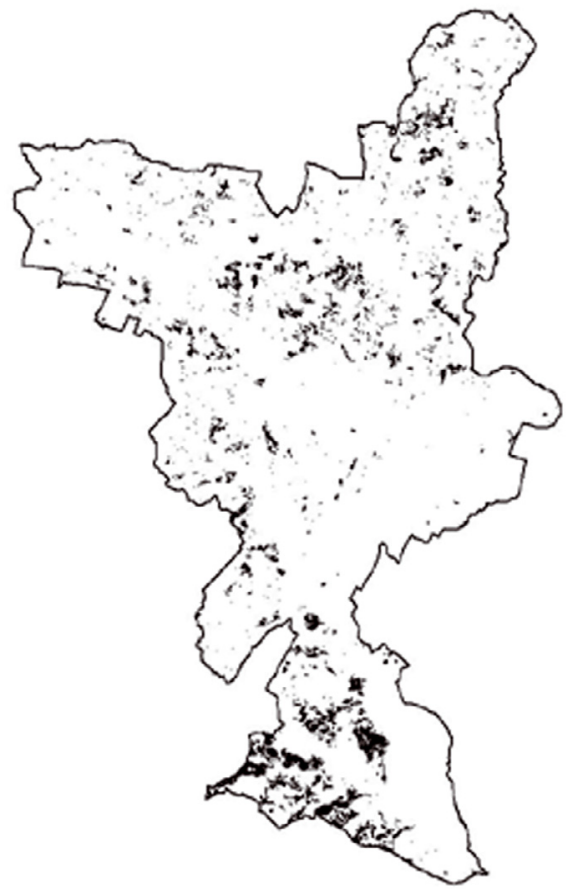

Figure 5. Cork oak predicted probability surface (cut value of 0.50 ) based on the logistic regression analysis of S. Bartolomeu da Serra area derived from cork oak mortality area in the year of 2005.

Spain), where a significant increase in competition between trees and understory for soil water and nutrients was observed when compared with cropped "dehesas" (Cubera et al., 2004; Montero et al., 2004).

The negative effect of shrub encroachment on the cork oak vegetation corroborates previous concerns regarding the progressive disappearance of cultivation and grazing that subsequently leads to shrub encroachment (Pinto-Correia and Mascarenhas, 1999). In fact, Brasier and Scott (1994) and Brasier (1996) suggested that Mediterranean oak decline could be associated with site disturbance (e.g. heavy animal trampling in open oak stands) or with land-use change (e.g. shrub encroachment). However, the effect of understory and landuse intensity may be negligible in cork oak woodlands that are managed for a sustainable cork production with extensive cultivation, as reported by Vacca (2000) for cork oak stands in Sardinia (Italy).

Higher cork oak mortality was observed in south-facing areas in relation to other orientations, which is in agreement with Cabral et al. (1992) and Sousa et al. (2000) who suggested that enhanced water stress may be caused by a more intense solar radiation. A similar trend was also reported by Brasier (1996) for holm oak and cork oak in Extremadura (Spain). In North America, Kabrick et al. (2008) also noticed that deciduous oak decline was more severe in southerly or south-westerly slopes. However, the effect of aspect in oak decline may be not so clear, as Cadima et al. (1995) did not observed a significant 
correlation between aspect and cork oak mortality in similar regions.

The results of the present study suggest that cork oak mortality is associated with soil depth. Indeed, in schist formations, the decline was stronger in Lepotosols, with lower depth overlying hard rock, than in Luvisols, although both had similar top soil chemical properties. The Leptosols developed on sedimentary formations also showed higher mortality than Arenosols, despite a lower organic matter and nutrient status in the latter.

The characteristics of soil parent material may also have an important role on cork oak mortality because mortality was stronger in Leptosols developed on sandstones than in those developed on schists. In both cases, the soil parent material is close to the surface and the reduced soil depth negatively influences the tree deep-rooting development (Fisher and Binkley, 2000). However, sandstones (mostly clay sandstones) are compacted and not fractured as it occurs in the schist formations (vertical fractures) (Inverno et al., 1993), which further inhibits the development of deep root systems and the access to below ground water resources during summer drought (Costa et al., 2008; David et al., 2007; Moreno et al., 2005).

The highest cork oak mortality was found in low to medium slopes, which correspond to the areas of the rounded hilltops and the smooth hillsides of the convex profile of the undulating landscape. This is in accordance with Cabral et al. (1992) and Cadima et al. (1995) who also observed higher cork oak mortality in similar slope classes. In such geomorphic conditions, stronger water deficit may occur due to the greater distance from roots to deep water. In hilltops, with shallow soils (Leptosols), the difficulty to access water resources may increase and therefore enhance the occurrence of tree decline. Nevertheless, when the soil depth allows the tree deep-rooting development, such as in Arenosols, even when located in hilltops, such trend may not occur, as reported by Costa et al. (2008). Similar conclusions were reported by Oak et al. (1996) in studies related to oak decline assessment in the southeastern United States, where the major decline occurred in lower slope gradients associated with xeric conditions. Our results emphasize that both slope and physiographic units should be taken into account in the assessment of cork oak mortality.

Regarding prediction of cork oak mortality using landscape features, the logistic regression model may underestimate the cork oak mortality, especially in woodlands. The low accuracy when predicting cork oak mortality in woodlands might be related to the absence (in the model) of tree related variables which have been reported as significant mortality predictors, such as: tree vigor (Fortin et al., 2008), age (Drobyshev et al., 2008) or biometric features, and cork exploitation intensity (Cabral et al., 1992; Cadima et al., 1995). This shows that, in agroforestry systems with a dominant forest component, it is insufficient to predict mortality at a patch level using only variables related to soil, slope and aspect, understory and canopy cover. Nevertheless, the model allowed correctly identifying the spatial and structural features of the areas with the highest cork oak mortality incidence.

\section{CONCLUSIONS}

In the Mediterranean region, cork oak mortality has a higher probability of occurrence in areas with land use disturbances mainly due to land use extensification (e.g. shrub encroachment in cork oak woodlands, or agriculture abandonment) and in xeric conditions, that is, in shallow soils in flat and southerly slope landforms. Overall, the site attributes consistently associated with cork oak mortality were those which contribute to tree water stress, by inhibiting either a deep root development or the access to groundwater which is the main reliable water source for evergreen oaks in Mediterranean woodlands.

The agroforestry management system and landscape features should be used with logistic regression procedures to predict major mortality incidence and therefore to identify "red signs" for cork oak mortality, which can be used for preventive or mitigation planning.

Acknowledgements: The first author thanks Fundação para a Ciência e a Tecnologia (Portugal) for a scholarship under the POCI 2010 Programme. The work was carried out with funding of Fundação para a Ciência e a Tecnologia (Portugal) to the Centro de Estudos Florestais. The cooperation of Direcção Geral dos Recursos Florestais and Núcleo Florestal do Alentejo Litoral (Portugal) is acknowledged. The authors thank the cooperation of Prof. Nuno Cortez regarding soil classification. The authors also acknowledge the comments of anonymous reviewers.

\section{REFERENCES}

Brasier C.M., 1996. Phytophthora cinnamomi and oak decline in southern Europe. Environmental constraints including climate change. Ann. Sci. For. 53: 347-358.

Brasier C.M. and Scott J.C., 1994. European oak declines and global warming: a theoretical assessment with special reference to the activity of Phytophthora cinnamomi. EPPO Bulletin 24(1): 221-232.

Bréda N., 2000. Water shortage as a key factor in the case of oak dieback in the Harth Forest (Alsatian plain, France) as demonstrated by dendroecological and ecophysiological study. In: Oszako T. and Delatour C., (Eds.), Recent advances on oak heath in Europe, Varsaw, Poland, pp. 157-160.

Cabral M.T., Ferreira M.C., Moreira T., Carvalho E.C., and Diniz A.C., 1992. Diagnóstico das causas da anormal mortalidade dos sobreiros a Sul do Tejo. Scientia gerundensis 18: 205-214.

Cabral M.T., Lopes F., and Sardinha R.M., 1993. Determinação das causas da morte do sobreiro nos concelhos de Santiago do Cacém, Grândola e Sines. Relatório Síntese. Silva Lusitana 1: 7-24.

Cadima I.S.P., Capelo J., and Gomes A.A., 1995. Relação entre variáveis ambientais, tipos de condução dos povoamentos e a mortalidade do sobreiro nos concelhos de Sines, Grândola e Santiago do Cacém. Silva Lusitana 3(1): 85-107.

Cardoso J.V.C., 1965. Os solos de Portugal. Sua classificação, caracterização e génese. 1 - A Sul do rio Tejo, D.G.S. A., Lisboa.

Costa J.C., Aguiar C., Capelo J.H., Lousã M., and Neto C., 1998. Biogeografia de Portugal Continental. Quercetea 0: 5-56.

Costa A., Pereira H., and Oliveira A.C., 2002. Influence of climate on the seasonality of radial growth of cork oak during a cork production cycle. Ann. For. Sci. 59: 429-437.

Costa A., Madeira M., and Oliveira A.C., 2008. The relationship between cork oak growth patterns and soil, slope and drainage in a cork oak woodland in Southern Portugal. For. Ecol. Manage. 255: 1525-1535. 
Cubera E., Montero M.J., and Moreno G., 2004. Effect of land use on soil water dynamics in dehesas of Central-Western Spain. In: Schnabel, S. and Ferreira, A. (Eds.), Sustainability of agrosilvopastoral systems - dehesas, montados, Advances in GeoEcology 37, Catena Verlag, Reiskirchen, pp. 109-123.

David T.S., Cabral M.T., and Sardinha R.M.A., 1992. A mortalidade dos sobreiros e a seca. Finisterra XXVII: 17-24.

David T.S., Henriques M.O., Kurz-Besson C., Nunes J., Valente F., Vaz M., Pereira J.S., Siegwolf R., Chaves M.M., Gazarini L.C., and David J.S., 2007. Water-use strategies in two co-occurring Mediterranean evergreen oaks: surviving the summer drought. Tree Physiol. 27: 793-803.

DGF, 2001. Inventário Florestal Nacional, Portugal Continental $-3^{\text {a }}$ Revisão 1995-1998. Direcção Geral das Florestas, Lisboa.

DGRF, 2007. Resultados do Inventário Florestal Nacional 2005/06. Inventário Florestal Nacional. Direcção-Geral dos Recursos Florestais, Lisboa.

Diniz A.C., 1994. Os solos do montado e aptidão suberícola nos concelhos de Grândola, Santiago do Cacém e Sines. Correlações com a morte prematura do sobreiro. Silva Lusitana 2: 247-267.

Drobyshev I., Niklasson M., Linderson H., Sonesson K., Karlsson M., Nilsson S.G., and Lanner J., 2008. Lifespan and mortality of old oaks - combining empirical and modelling approaches to support their management in southern Sweden. Ann. For. Sci. 65: 401.

Ferreira F., 2000. The cork oak condition in Portugal. In: Oszako T. and Delatour C., (Eds.), Recent advances on oak heath in Europe, Varsaw, Poland, pp. 121-130.

Fisher F.R. and Binkley D., 2000. Ecology and management of forest soils. 3rd ed. John Wiley \& Sons, New York, USA.

Fortin M., Bédard S., Deblois J., and Meunier S., 2008. Predicting individual tree mortality in northern hardwood stands under uneven-aged management in southern Québec, Canada. Ann. For. Sci. 65: 205.

Inverno C.M.C., Manuppella G., Zbyszewski G., Pais J., and Ribeiro M.L., 1993. Carta Geológica de Portugal na escala 1: 50000-42C. Notícia explicativa da Folha 42 C Santiago do Cacém. Serviços Geológicos de Portugal, Lisboa.

Kabrick J.M., Dey D.C., Jensen R.G., and Wallendorf M., 2008. The role of environmental factors in oak decline and mortality in Ozark Highlands. For. Ecol. Manage. 255: 1409-1417.

Kurz-Besson C., Otieno D., Vale R.L., Siegwolf R., Schmidt M., Herd A., Nogueira C., David T.S., Tenhunen J., Pereira J.S., and Chaves M., 2006. Hydraulic lift in cork oak trees in a savannah-type Mediterranean ecosystem and its contribution to the local water balance. Plant Soil 282: 361-378.

Moniz M., Tomaz I., Cabral M., and Basto M., 1996. Avaliação da patogenicidade de Phyphtora cinnamomi Rands em sobreiro (Quercus suber L.). Silva Lusitana 4: 79-88.
Montero M.J., Obrador J.J., Cubera E., and Moreno G., 2004. The role of dehesa land use on tree water status in Central-Western Spain. In: Schnabel S. and Ferreira A. (Eds.), Sustainability of agrosilvopastoral systems - dehesas, montados, Advances in GeoEcollgy 37, Catena Verlag, Reiskirchen, pp. 125-136.

Moreno G., Obrador J.J., Cubera E., and Dupraz C., 2005. Fine root distribution in dehesas of Central-Western Spain. Plant Soil 277: 153162.

Oak S., Tainter F., Williams J., and Starkey D., 1996. Oak decline risk rating for the southeastern United States, Ann. Sci. For. 53: 721-730.

Oliveira G., Correia O.A., Marins-Loução M.A., and Catarino F.M., 1992. Water relations of cork oak (Quercus suber L.) under natural conditions. Vegetatio 99-100: 199-208.

Oszako T., 2000. Oak declines in Europe's forest - history, causes and hypothesis. In: Oszako T. and Delatour C., (Eds.), Recent advances on oak heath in Europe, Warsaw, Poland, pp. 11-40.

Pereira H. and Tomé M., 2004. Non-wood products: Cork Oak. In: Burley J., Evans J., and Youngquist J.A. (Eds.), Encyclopedia of Forest Sciences. Elsevier, Oxford, pp. 613-620.

Pereira J.M.C. and Santos T.N., 2003. Fire risk and burned are mapping in Portugal, DGF, Lisboa.

Pinto-Correia T. and Mascarenhas J., 1999. Contribution to the extensification/intensification debate: new trends in the Portuguese montado. Landsc. Urban Plan. 46: 125-131.

Pinto-Correia T. and Vos W., 2004. Multifunctionality in Mediterranean landscapes - past and future. In: Jongman R. (Ed.), The new dimensions of the European landscape, Springer, Berlin, Wageningen, EU Frontis Series, pp. 135-164.

SROA, 1962. Carta de Solos de Portugal na escala 1:50 000. Folha 42C. Serviço de Reconhecimento e Ordenamento Agrário. Secretaria de Estado da Agricultura, Ministério da Economia, Lisboa.

Sousa E., Pinto J., Santos M., Gomes A., and Bonifácio L., 2000. Association of soil macro and microelements and cork oak decline in Portugal. In: Oszako T. and Delatour C. (Eds.), Recent advances on oak heath in Europe, Warsaw, Poland, pp. 215-218.

SPSS, 2008. SPSS 15.0 vs. for Windows.SPSS Inc., Chicago.

Thomas F.M., Blank R., and Hartmann G. 2002. Abiotic and biotic factors ant their interactions as causes of oak decline in Central Europe. For. Pathol. 32: 277-307.

Vacca A., 2000. Effect of land use on forest floor and soil of a Quercus suber L. forest in Gallura (Sardinia, Italy). Land Degrad. Dev. 11: 167-180.

Wargo P.M., 1996. Consequences of environmental stress on oak: predisposition to pathogens. Ann. For. Sci. 53: 359-368.

WRB, 2006. World reference base for soil resources. A framework for international classification, correlation and communication. World Soil Reports 103, 2nd ed., FAO, Rome. 